IRA-International Journal of Management \& Social Sciences

ISSN 2455-2267; Vol.05, Issue 03 (2016)

Pg. no. 479-490

Institute of Research Advances

http://research-advances.org/index.php/RAJMSS

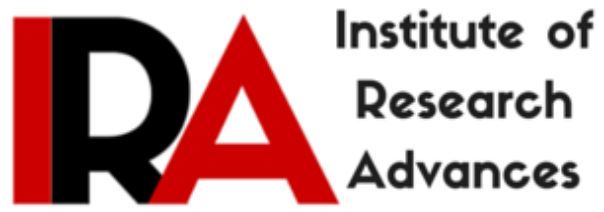

\title{
Application of TQM for Customer Service in Relationship Marketing
}

\section{Dr. Fasil Taddes}

Assistant professor

Mekelle University, Mekelle, Tigray, Ethiopia.

Type of Review: Peer Reviewed.

DOI: http://dx.doi.org/10.21013/jmss.v5.n3.p11

How to cite this paper:

Taddes, F. (2016). Application of TQM for Customer Service in Relationship Marketing. IRA-International Journal of Management \& Social Sciences (ISSN 2455-2267), 5(3), 479-490. doi:http://dx.doi.org/10.21013/jmss.v5.n3.p11

(C) Institute of Research Advances

\section{(cc) EY-NC}

This work is licensed under a Creative Commons Attribution-Non Commercial 4.0 International License subject to proper citation to the publication source of the work.

Disclaimer: The scholarly papers as reviewed and published by the Institute of Research Advances (IRA) are the views and opinions of their respective authors and are not the views or opinions of the IRA. The IRA disclaims of any harm or loss caused due to the published content to any party. 
IRA-International Journal of Management \& Social Sciences

\begin{abstract}
One of the contributions of TQM is the consideration of customers as integral part of the business. Meanwhile, modern marketing practices call for greater focus on relationship marketing. Although research shows that TQM plays a mediating role in marketing, clear mediating role has not been established. This research tries to investigate the areas where TQM plays the mediating role in relationship marketing. To achieve this, an inductive exploratory research is done by taking 10 different companies that have applied TQM for customer service operations. The result shows that TQM is used to address different customer base needs in equal and satisfactory manner by developing appropriate strategies aligned to the different customer needs. The main mediating role played by TQM was the consideration of different customer spans in revolutionizing traditional marketing approaches to more customized and differentiated relationship marketing strategies. TQM is applied to strategically incorporate different customer needs into one marketing spectrum by strategizing the relationship marketing platform.
\end{abstract}

Key Words: TQM, Customer Needs, Customer Service, Relationship Marketing, Deming Award

\title{
INTRODUCTION
}

Good customer service has been the lifeblood of modern business (Grönroos 1994; Peeler 1996) by creating a strong customer loyalty (Fornell 1992; Mosahab et al. 2010; Oliver 1981). In traditional marketing, promotion and price cutting have been used as strategy to bring as many new customers as possible (Slater and Narver 1994). However, it is argued that, with such approach, maintaining customers for long time is difficult. Parasuraman (1998) underlined that, as competition becomes intense, traditional marketing cannot be effective. Hence, there will be a prompted shift to customer oriented approach. Because, unless businesses can get some of those customers come back for another purchase, the business will not be profitable for long (Goofin and Price 1996). Literally speaking, good customer service is all about bringing customers back and sending them away happy aiming for a second purchase. Customers need to be happy enough about their purchase to pass positive feedback about their business transaction to others (Kotler 2000). Then, these new customers may try the product or service offered for them and in their turn become repeat customers. Such customers then become loyal to the supplier (Boeselie et al. 2002; Hansemark and Albinson 2004). Therefore, this is what makes a business successful where the customers are happy and ready for another purchase.

Meanwhile, TQM is advocated for promoting customer service and satisfaction in many literatures. Hence, if TQM is applied, loyal customers must by default be observed in TQM companies. While maintaining the fact that TQM has provided better performance for companies that implement, the market success of companies is also what TQM must be checked if it really mediates marketing. Therefore, this research aims at studying the role of TQM in relationship marketing.

\section{Developments in Customer Service}

In traditional marketing, a good salesperson can sell anything to anyone once. But, the company's ability to sell that same person some other time is determined by the approach to the customer service (Oliver 1999; Zineldin and Philipson 2007). The essence of good customer service underlines the forming of good relationship with customers that sustains for long-term. This relationship however needs to be a relationship that the individual customer feels would like to pursue (Kohli and Jaworski 1990). Hence, such relationships may be affected through various structures such as nearness to the market, objectivity in long-term relationship, technical and operational conditions, and competitive advantages of the relationship (Bitner et al. 2002; Edvardsson et al. 1989; Gummesson and Grönroos 1987). In addition, building long-term relationship with customers and the approach may require orientations that focus towards business partnership. On the other hand, customer relationship management may need its own direction in creating value both for the supplier and customer (Sila and Ebrahimpour 2005). In this regard, sharing market information between supplier and customers including future market trends and market 
directions may enable both parties to take timely business decisions, strengthen the relationship and sustain it (Taleghani, et al. 2011). In this regard, TQM may play a major role in establishing and sustaining such relationship between companies and their customers. Therefore, the current developments in customer service show a trend of strategy alignment and relationship between suppliers and their customers.

\section{The Concept of Relationship Marketing and Customer Service}

The concept of relationship marketing and customer service has been in the agenda of researchers for the last several years. Ndubisi $(2003,2006)$ outlined the importance of relationship marketing and customer service in terms of customer relationship. In another perspective, relationship marketing is viewed as the delivery of long-term value to customers as measured by the customer satisfaction level (Grönroos 1994; Murphy et al. 2005). Meanwhile, researchers have tried to identify factors that involve in the relationship marketing and customer service (Beetles and Harris 2010; Chattananon and Trimetsoontorn 2009; Gilaninia et al. 2011; Kavali et al. 1999). In other literatures, customer relationship and customer service are treated in much closer context to market orientation perspectives (Heffernan et al, 2008; Mohammad et al. 2011; Patsioura et al. 2009; Wouters 2004). Hence, customer relationship and customer service are used interchangeably in some literature. Nevertheless, in this research, these two are treated differently. While customer relationship is considered as the relationship that is intertwined by strategy alignment, customer service is considered as the provision of support at any given time.

\section{TQM and Customer Service}

The concept of market orientation has been widely argued for its effect on customer services. Meanwhile, TQM is also tipped with its potential to shape firm's orientation in the direction of customer service. Many researchers have tried to draw a meaningful picture of these contexts. For example: Kohli and Jaworski (1990) and Jaworski and Kohli (1993) have tried to develop a conceptual and empirical framework on market orientation. Other models of the same are also developed by Narver and Slater (1990) and Slater and Narver (1995, 1999). In these literatures, market orientation is associated with direction followed by companies while customer service is associated with handling of customer needs.

In some literature, it is reported that TQM and market orientation share some common dimensions (Chadam and Pastuszak 2005; Davig et al. 2003; Mandal, 2000; Moreno et al. 2005). One such dimension is the understanding of customers' needs and satisfying it thereafter. Ishikawa (1985) underlined that organizations must know the customers' want and set out the desired product and service quality. Kanji and Asher (1993) also have stated that the performance of an organization merely is depicted in the customer satisfaction. Therefore, it can easily be concluded that a TQM company would be good in its customer service thus promoting market success.

\section{RESEARCH DESIGN AND METHODOLOGY}

\section{Research Design}

Often TQM is highly associated with managing operations at optimum level by the involvement of internal and external stakeholders of an organization (Motwani 2001). Meanwhile, marketing often looks to the effectiveness of an organization's operations in securing sales. At this juncture, many researchers agree that marketing relationship is important to ensure profound base for business to continue between suppliers and customers (Appiah-Adu and Singh 1988; Liu 1995; Pit et al. 1996; Slater and Narver 1994). It is highly advocated that, TQM through its customer oriented system mediates the marketing strategy of companies (Mele 2007).

Taking this background, this research tries to understand the underlining environment behind the application of TQM for customer service in marketing relationships. Five (5) Deming Grand Prize winners and Five (5) Deming Prize wining companies are studied in this research. The companies are shown in Table-1. 
Table-1: List of Companies Studied

\begin{tabular}{|l|l|l|l|}
\hline SNo. & Company Name & Industry & Winner of \\
\hline 1 & Tata Steel (TS) & Steel & Deming Grand Prize \\
\hline 2 & Mahindra and Mahindra FES (MMFES) & Farm Equipment & Deming Grand Prize \\
\hline 3 & Thai Acrylic Fiber (TAF) & Chemical & Deming Grand Prize \\
\hline 4 & Rane Brakes Lining (RBL) & Automotive & Deming Grand Prize \\
\hline 5 & Rane Madras Ltd. (RML) & Automotive & Deming Grand Prize \\
\hline 6 & Mahindra and Mahindra Powerol (MMP) & Engine & Deming Prize \\
\hline 7 & Indo Gulf Fertilizers (IGF) & Chemical & Deming Prize \\
\hline 8 & RSB Transmission (RSBT) & Automotive & Deming Prize \\
\hline 9 & Siam Mitsui PTA (SMPTA) & Chemical & Deming Prize \\
\hline 10 & SCG Logistics (SCGL) & Logistics & Deming Prize \\
\hline
\end{tabular}

While the companies selected are deemed to incorporate both categories of the award, the research methodology was selected to unearth the different approaches followed by each company and then induct the learning points for the application of TQM for customer service in marketing relationship.

\section{Research Methodology}

Since this research is based on learning from practice, the research methodology utilized is an inductive research method (Figure 1) in an exploratory research approach. Exploratory research has been in use quite often and especially when industrial practices are different from one company to another in the same industrial issues. Therefore, as a research methodology of exploratory and inductive nature, this research has tried to observe the practices of the companies in applying TQM for customer service in terms of marketing relationships. From such observation, the research has tried to establish patterns that generally can explain the application of TQM for the purpose of customer service in marketing relationships. Finally, a conclusion is developed that compiles the observations and patterns into an academic knowledge.

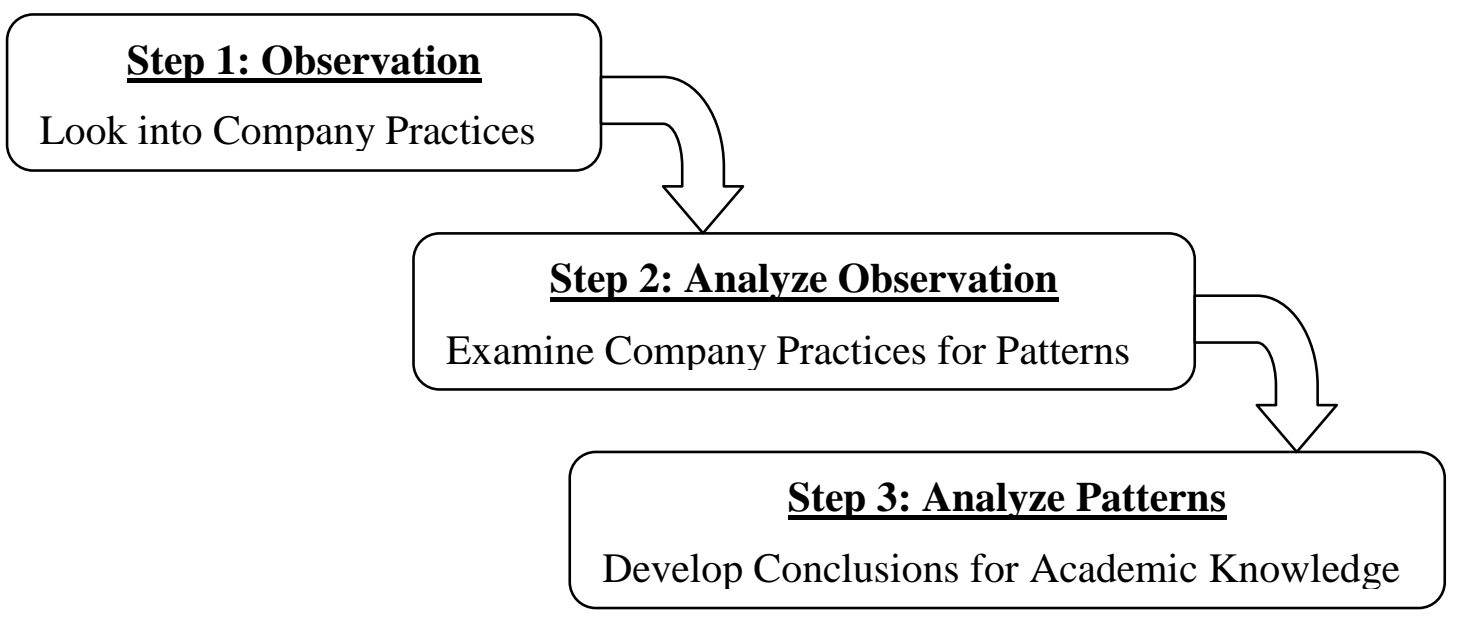

Fig. 1: Research Methodology

While the research methodology followed is stated in Figure 2, the study points utilized were:

- Customer span

- Marketing strategy (Old type and TQM based (Game Changer Strategy))

- The applied change model (change in market orientation) and

- The results achieved thereafter (either market share or customer satisfaction index) 


\section{RESEARCH OBSERVATION, ANALYSIS AND DISCUSSION}

\section{Introduction}

Relationship between suppliers and customers is very important aspect of business. However, the desire of both parties (suppliers and customers) does not always match. In such situation, many companies are always observed to have a wavering stand on their suppliers or customers. The fact is that the direction in which the supplier or the customer follows becomes incompatible with the other party. This circumstance makes relationships between suppliers and customers to be short term oriented. Meanwhile, it is advocated that TQM promotes long term relationship between supplier and customer. Hence, in modern business management practices, this nature of TQM is considered as key to successful business. In this regard, strategy alignment between the supplier and customer will be very crucial if the journey is to be compatible for longer time. Therefore, the first observation made in this research is how suppliers have developed adaptable market strategy to address the wants of their customers.

\section{Research Observations}

Table-2 outlines that how each company in this study has approached to the long term relationship establishment of supplier-customer. From Table-2, it can be observed that the type of customers for each supplier is diversified. That means single marketing strategy cannot serve all of the customers. This is due to the fact that all customers may not have the same wants. It is also observed that all companies have a lot of variability to handle when dealing with customer services. This variation is observed in terms of the customer span they have, market strategy followed applied change models and the success achieved. The detail of these is discussed in the research analysis part of this manuscript.

Table-2: Marketing Strategies Before and After TQM

\begin{tabular}{|c|c|c|c|c|c|c|}
\hline \multirow{3}{*}{ SNo. } & \multirow{3}{*}{ Company } & \multicolumn{4}{|c|}{ TQM Practices for Customer Service } & \multirow{3}{*}{ Results Achieved } \\
\hline & & \multirow{2}{*}{$\begin{array}{l}\text { Customer } \\
\text { Span }\end{array}$} & \multicolumn{2}{|c|}{ Market Strategy } & \multirow{2}{*}{$\begin{array}{l}\text { Applied } \\
\text { Change } \\
\text { Model }\end{array}$} & \\
\hline & & & Old Type & TQM Based & & \\
\hline 1 & A & Diversified & Product based & Value based & $\begin{array}{l}\text { Value chain } \\
\text { management }\end{array}$ & $\begin{array}{l}\text { Increased the share } \\
\text { of its brand } \\
\text { products from } 11 \% \\
\text { to } 34 \% \text { in four } \\
\text { years }\end{array}$ \\
\hline 2 & B & Diversified & $\begin{array}{l}\text { Market } \\
\text { position }\end{array}$ & Service based & $\begin{array}{l}\text { Customer } \\
\text { service and } \\
\text { outreach }\end{array}$ & $\begin{array}{l}\text { Attained market } \\
\text { share of more than } \\
40 \% \text { in four years }\end{array}$ \\
\hline 3 & $\mathrm{C}$ & Diversified & Spot sales & $\begin{array}{l}\text { Product and } \\
\text { Service based }\end{array}$ & $\begin{array}{l}\text { Product } \\
\text { customization } \\
\text { and Customer } \\
\text { service }\end{array}$ & $\begin{array}{l}\text { Customer } \\
\text { satisfaction index } \\
\text { has continually } \\
\text { increased from } \\
53.8 \% \text { to } 85.3 \% \text { in } \\
\text { six years }\end{array}$ \\
\hline 4 & $\mathrm{D}$ & Diversified & OEM tied & $\begin{array}{l}\text { Innovation } \\
\text { based }\end{array}$ & $\begin{array}{l}\text { Technological } \\
\text { innovation } \\
\text { and total } \\
\text { quality }\end{array}$ & $\begin{array}{l}\text { Attained a } \\
\text { customer } \\
\text { satisfaction index } \\
\text { of } 96 \% \text { from } 76 \% \\
\text { in five years }\end{array}$ \\
\hline 5 & $\mathrm{E}$ & Diversified & OEM tied & Outreach & $\begin{array}{l}\text { Customized } \\
\text { sales outlets }\end{array}$ & $\begin{array}{l}\text { Acquired new sales } \\
\text { business worth of } \\
\$ 11 \text { million in just } \\
\text { four years }\end{array}$ \\
\hline
\end{tabular}




\begin{tabular}{|l|l|l|l|l|l|l|}
\hline 6 & F & Diversified & GOEM tied & $\begin{array}{l}\text { Innovation } \\
\text { based }\end{array}$ & $\begin{array}{l}\text { Diversified } \\
\text { technological } \\
\text { innovations }\end{array}$ & $\begin{array}{l}\text { Market share has } \\
\text { continually } \\
\text { increased more } \\
\text { than planned }\end{array}$ \\
\hline 7 & G & Diversified & Sales based & Service based & $\begin{array}{l}\text { Customer } \\
\text { service }\end{array}$ & $\begin{array}{l}\text { Attained a market } \\
\text { share of 48\% from } \\
18 \% \text { in just four } \\
\text { years }\end{array}$ \\
\hline 8 & H & Diversified & $\begin{array}{l}\text { Business } \\
\text { volume }\end{array}$ & $\begin{array}{l}\text { Overall } \\
\text { business } \\
\text { improvement }\end{array}$ & $\begin{array}{l}\text { Strategic } \\
\text { business } \\
\text { management }\end{array}$ & $\begin{array}{l}\text { Develop } \\
\text { technology that } \\
\text { have more than } \\
\text { 50\% market share }\end{array}$ \\
\hline 9 & I & Diversified & - & $\begin{array}{l}\text { Project based } \\
\text { market } \\
\text { success }\end{array}$ & $\begin{array}{l}\text { Capacity } \\
\text { improvement }\end{array}$ & $\begin{array}{l}\text { Attained } \\
\text { market share in five } \\
\text { years }\end{array}$ \\
\hline 10 & J & Diversified & $\begin{array}{l}\text { Structured } \\
\text { service }\end{array}$ & $\begin{array}{l}\text { Customized } \\
\text { service }\end{array}$ & $\begin{array}{l}\text { Stakeholders } \\
\text { management }\end{array}$ & $\begin{array}{l}\text { Dominated selected } \\
\text { market shares by } \\
\text { more than 10\% for } \\
\text { six consecutive } \\
\text { years }\end{array}$ \\
\hline
\end{tabular}

\section{Research Analysis (Pattern of Practices)}

(1) Customer span and handling. From the observation (Table-2), it is clear that all the companies under this study have diversified customers. The nature of diversity is dependent on the type of business. It is observed that with the same business the nature and need of the customers are not homogeneous. However, although the supplier companies have their own business objectives and business processes, they have customized their business processes to address the needs of each customer in unique way in their TQM based market strategies. The motive to change in to such model is that this type of customers needed different handling. For better customer service, the suppliers needed to understand the customer's need for its service operation. It also needed the identification of critical factors that make the service operation attractive to the customer. These situations force a unique and customized service to customers. Two reasons were observed why a customer was given a customized service from the supplier. The two cases that have needed such a unique and customized service in this study are: (1) A supplier provides a customized service to a customer so as to make the reach to the final market achieved (Figure-2, case-1). This is so important especially when the final market success (user end) will highly be affected by the performance of the primary customer. (2) A customer demands a customized service from supplier so as to ensure there is attendance in the final market that may need extra assistance to the end user (Figure-2, case-2). This is so important in the situation when the primary customer itself needs assistance to win the end market.

Case-1

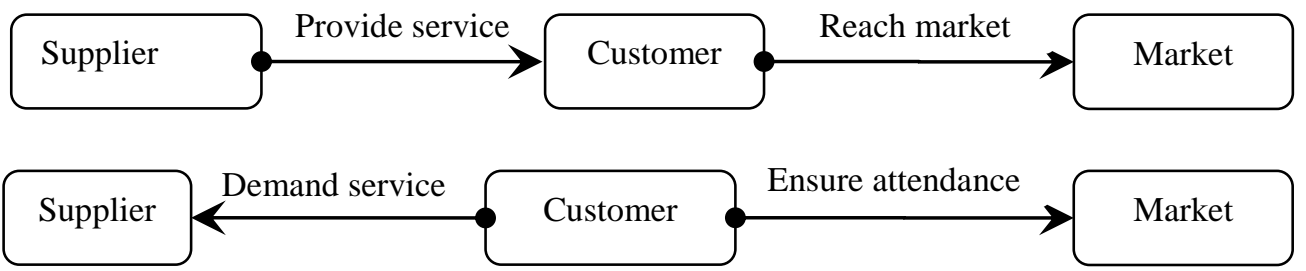

Fig. 2: Cases where customer service is required 
Market strategy. In the market strategy, the companies have followed a strategy change from traditional to TQM oriented to incorporate the unique service demanded by their customers. As can be seen in Table-2, most companies have changed their market strategy from specific approach to generic approach. This has helped them have the power to flexibly address different customer needs and provide customized customer services._In both cases, TQM is used as methodology to achieve market interests by creating trusted relationship between supplier and customer. For example, Figure3 illustrates how one company has changed its market strategy to incorporate customized customer needs.

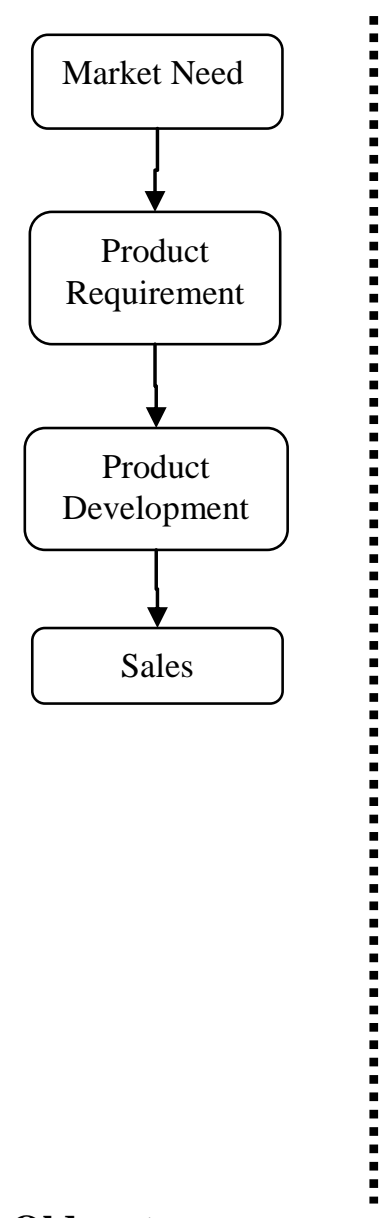

Old system

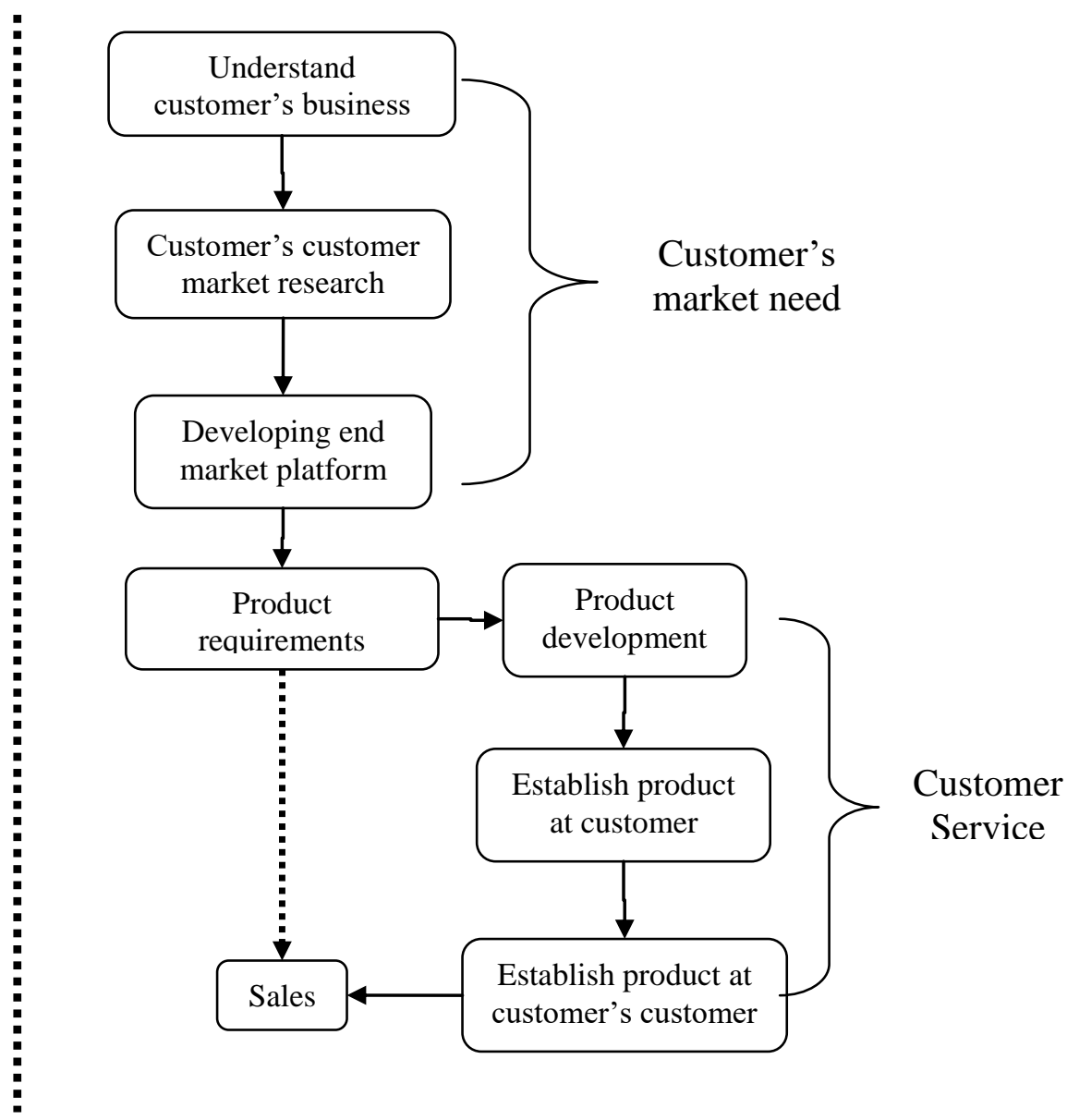

TQM system

Fig. 3: Changing strategy to incorporate unique customer needs

Applied Change Model. In this pattern, the companies have shown a change of strategy from short term winning approach to long term winning systems. For example one company has changed from bare value approach which mainly considered what value is being delivered by the product to the value chain management. This new approach focuses not only on the value created but also how this value flows from the start to the end customer. Thus, allowing the company to address the complete value system with regards to the different customer bases buying its products. The other companies, in their own contexts have applied different change models that best suits to their business. But, the bottom line for all the companies was to move from a specific short term market winning approach to long term but customizable marketing strategy. Hence, the importance of TQM was to serve as a platform for a totality but customized approach of marketing strategies. This finally benefits the supplier, the supplier's customers, and the customer's customers. That is the entire market 
relationship in a long term basis. Figure 4 shows how the company has revolutionized its marketing strategy from a traditional short term orientation to long term relationship based marketing system. The revolution is to add the customer service division to the traditional marketing system, then adding objective tasks for this division to look to the long term relationship.

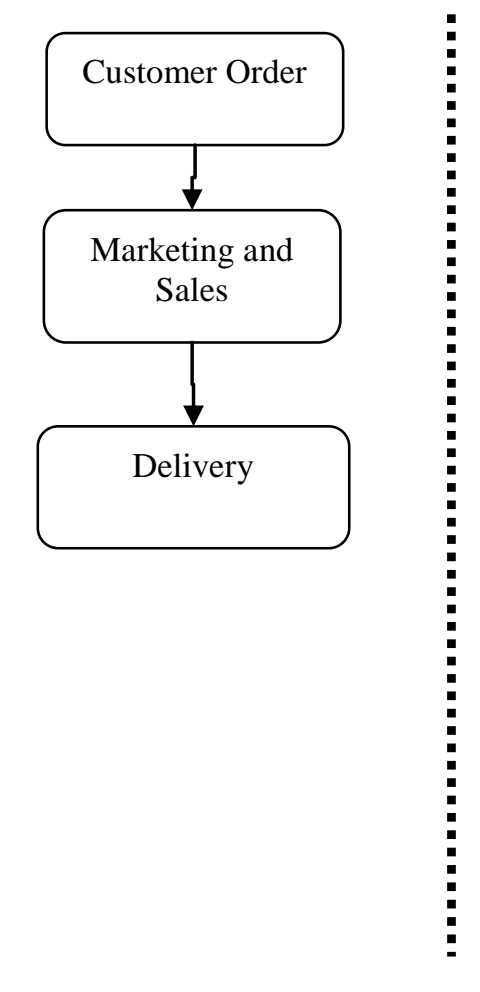

Traditional Marketing System

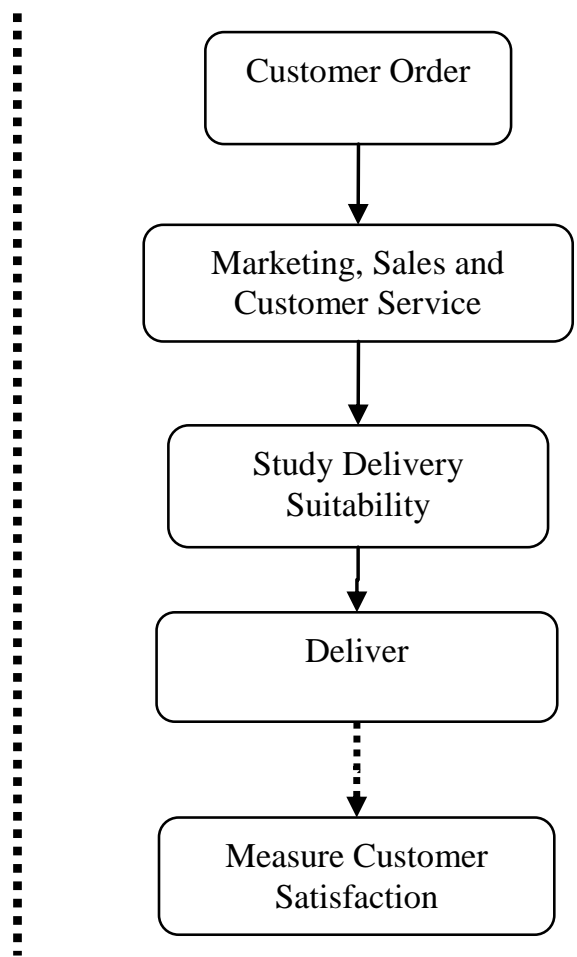

\section{TQM Marketing System}

Fig. 4: Applied Changing Strategy at Example Company

Results achieved. As can be seen in Table 2, the application of TQM to marketing practices has shown steady growth over years. Although the results achieved are significant, one must note that this success will need time to manifest itself. The bottom line is that once such results are achieved, the continuity of the success is guaranteed. This is so for two reasons as shown in Figure 2. The market relationship between supplier and customer always will look for the two possible scenarios. 1) The supplier does not want to fail in the final market. So, continually supporting its customers, who take its products to the final end customer, is mandatory. 2) Customers who buy products/services from suppliers do not want to be abandoned once they bought the product/service. They need a regular follow-up from the supplier if they are to rely in buying the product/service from that supplier again. In either case, if the objective of marketing is short term success, TQM may not be helpful; but if the objective is a long term one, such relationship is mandatory and TQM can help a lot.

\section{Discussion}

In this study, the way companies have addressed customized customer services was observed to be triggered by two major primary customer circumstances. However, the bottom line was that supplier companies needed to assure their customers will remain as integral part to their systems hence business will continue under different situations. The circumstances observed in this study reflected two doubts of customers: 
$>$ Customer's fear of their business situation if there is change of leadership at the supplier. In this study, it is observed that suppliers took initiative of exhaustively studying the end market situation in consultation with their customers. This was done due to the fact that customers become anxious of relying on one supplier for major part of their business. in such circumstance customers become unsure about what will happen to their business if there will be change of leadership at the supplier side. It is noted that customers feel there is a change of marketing regime when there is leadership change and maintaining past relationship becomes difficult in the new regime. In such circumstances customers want to make sure they are attended by their supplier at all times. For example, in one of the companies studied, one customer gets $50 \%$ of its supply from the company. But this customer had doubts of the long term situation of the business relationship. Three things were very critical for the customer if there would be change of leadership at the Supplier Company.

i) Continuation of the quality principles by the new regime,

ii) Pricing approach of the new regime, and

iii) The continued status of the company as important customer by the new regime.

Therefore, the customer company needed the supplier to clear the doubts on the mentioned customer concerns. As a result the long term relationship was made to be founded on concrete base of establishing joint projects, principled price negotiation, resolving quality issues, and development of detailed guidelines and standards for the bilateral relationship. These measures created more comfort and easiness of the customer of being served by its supplier.

$>$ Outlet channels provide indifferent service as compared to competitors. Customers feel indifferent of buying any alternative product existing in the market. This makes customers swing from one supplier to another which affects sales objectives. Therefore, close follow-up to the final market and how it is functioning is mandatory for suppliers if they are to maintain their market position or want to expand it. For example, one of the studied companies has developed improved products that are capable of beating competitors' products. However, customer satisfaction remained low despite such a highly competitive product. When a study is conducted to rectify the problem, two things were identified.

i) There was little or no difference in customer service between the company and its competitors at the end market and

ii) There was no uniform service operation provided by all dealers of the company

As a result, although there was quality product in the market, no market exception was seen for the product. Therefore, the company has decided to extend its operations in customer service to its dealers (customers) and end users (customer's customers) to ensure the two problems are solved. By doing so, the company was able to attract customer attention and create the feel of connectivity to the source company. This has given the company very good market competitiveness and a trustful relationship with its customers.

\section{CONCLUSION}

It is fundamental to note that in traditional marketing, Marketing and Sales are the front line departments interacting with the customers. However, today's customers need much attention by their suppliers than the mere buy and sell operation. As manufacturing firms operate through a cycle of "Source - Plan Make - Deliver"; Customer Service operations must be incorporated in to their marketing and sales operations. These units can be tasked to link the "Deliver" to the context of each customer's needs. Unique customer technical/operational support services and a strategy customization to improve the customers' productivity can help suppliers to develop loyal and regular customers that can give them a competitive advantage. With such circumstances, TQM can proactively help companies to always maintain strong market intelligence and continuously track the developments in their customers and 
customers' markets. Hence, TQM can help the creation of a very effective customer services that can be translated to the equivalence of relationship marketing.

\section{LIMITATIONS}

While the content in this paper is absolutely based on company data, the analysis is basically of an inductive one. Pattern in the companies is interpreted based on the presentation made by each company. Therefore, company interpretations may be different from the study pattern interpretation in this study. Hence, readers are advised to consider that there may be difference in interpretation between the companies and the research. The interpretation here is only done for academic purpose.

\section{References}

1. Appiah-Adu, K., and Singh, S., (1988), Market orientation and performance: An empirical studies of British SMEs, Journal of Entrepreneurship, Vol. 7, No. 1, pp. 27-47

2. Beetles, A.C., and Harris, L.C., (2010), The role of intimacy in service relationships: an exploration, Journal of Services Marketing, Vol. 24, No. 5, pp. 347-358

3. Bitner, M.J., Brown, S.W., and Meuter, M.C., (2002), Technology Infusion in Service Encounters, Journal of the Academy of Marketing Science, Vol. 28, No. 1, pp. 138-149

4. Boeselie, P., Hesselink, M., and Wiele, T.V., (2002), Empirical evidence for the relationship between customer satisfaction and business performance, Managing Service Quality, Vol. 12, No. 3, pp. 184193

5. Chadam, J. and Pastuszak, Z. (2005), Marketing aspects of knowledge-based management in groups of companies: case of Poland, Industrial Management \& Data Systems, Vol. 105, pp. 459-75

6. Chattananon, A., and Trimetsoontorn, J., (2009), Relationship marketing: a Thai case, International Journal of Emerging Markets, Vol. 4, No. 3, pp. 252-274

7. Cunningham, M.T, and Roberts, D.A, (1974), The Role of Customer Service in Industrial Marketing, European Journal of Marketing, Vol. 8, No. 1, pp 15-28

8. Davig, W., Brown, S., Friel, T. and Tabibzadeh, K. (2003), Quality management in small manufacturing, Industrial Management \& Data Systems, Vol. 130, No. 2, pp. 68-77

9. Edvardsson, B., Gustavsson, B.O., and Riddle, D.I., (1989), An Expanded Model of the service Encounter with Emphasis on Cultural Context, research report 89:4, CFT services research Center, University of Karlstad, Sweden

10. Fornell, C., (1992), A National Customer Satisfaction Barometer: The Swedish Experience. Journal of Marketing, Vol. 56, No. 1, pp. 6-21

11. Gilaninia, S., Almani, A.M., Pournaserani, A., and Mousavian, S.J., (2011). Relationship Marketing: a New Approach to Marketing in the Third Millennium, Australian Journal of Basic and Applied Sciences, Vol. 5, No. 5, pp. 787-799

12. Goffin, K., and Price, D., (1996), Service Documentation and the Biomedical Engineer: Results of a Survey, Biomedical Instrumentation and Technology, Vol. 30, No. 3, pp.223-230

13. Grönroos, C., (1994), From Marketing Mix to Relationship Marketing: towards a paradigm shift in marketing, Management Decision, Vol. 32, No. 2, pp. 4-20

14. Gummesson, E., and Grönroos, C., (1987), Quality of Products and Services: A tentative synthesis between two models, Research Report 87:3, Service Research Center, University of Karlstad, Sweden

15. Hansemark, O. C. and Albinson, M., (2004), Customer Satisfaction and Retention: The Experiences of Individual with Employees", Managing Service Quality, Vol. 14, No. 1 
16. Heffernan, T., O'Neill, G., Travaglione, T., and Droulers, M., (2008), Relationship marketing: The impact of emotional intelligence and trust on bank performance, International Journal of Bank Marketing, Vol. 26, No. 3, pp. 183-199

17. Ishikawa, K. (1985), What Is Total Quality Control? The Japanese Way, Prentice-Hall, London

18. Jaworski, B.J., and Kohli, A.K., (1993), Market orientation: antecedents and consequences, Journal of Marketing, Vol. 57, No. 3, pp. 53-70

19. Kanji, G.K. and Asher, M. (1993), Total Quality Management Process: A Systematic Approach, Advances in Total Quality Management Series, Carfax, Abingdon.

20. Kavali, S., Tzokas, N.X., and Saren, M.J., (1999), Relationship marketing as an ethical approach: philosophical and managerial considerations, Management Decision, Vol. 37, No. 7, pp. 573-581

21. Kohli, A. K. and Jaworski, B. J., (1990), Market orientation: the construct, research propositions, and managerial implications, Journal of Marketing, pp. 1-18

22. Kotler, P. (2000), Marketing Management. $10^{\text {th }}$ edn., New Jersey, Prentice-Hall

23. Liu, H., (1995), Market orientation and firm size: An empirical examination in UK firms, European Journal of Marketing, Vol. 29, No. 1, pp. 57-71

24. Mandal, P., (2000), Interfunctional spread of quality in manufacturing, Industrial Management \& Data Systems, Vol. 100, No. 3, pp. 135-40

25. Mele, C., (2007), The synergic relationship between TQM and marketing in creating customer value, Managing Service Quality, Vol. 17, No. 3, pp. 240-258

26. Mohammad, T., Shahram, G., and Seyyed, J.M., (2011), the Role of Relationship Marketing in Customer Orientation Process in the Banking Industry with focus on Loyalty, International Journal of Business and Social Science, Vol. 2, No. 19, pp. 155-166

27. Moreno, A.R., Morales, V.G., and Montes, F.J.L., (2005), Learning the quality management process, Industrial Management \& Data Systems, Vol. 105, No. 8, pp. 1001-21

28. Mosahab, R., Mahamad, O., and Ramayah, T., (2010), Service Quality, Customer Satisfaction and Loyalty: A test of mediation, International Business Research, Vol. 3, No. 4, pp. $72-80$

29. Motwani, J., (2001), Critical Factors and Performance Measures of TQM, The TQM Magazine, Vol. 3, No. 4, pp. $292-300$

30. Murphy, B., Maguiness, P., Pescott, C.H., Wislang, S., Ma, J., and Wang, R., (2005), Stakeholder perceptions presage holistic stakeholder relationship marketing performance, European Journal of Marketing, Vol. 39, No. 9/10, pp. 1049-1059

31. Ndubisi, N.O., (2003), Service quality: understanding customer perception and reaction, and its impact on business, International Journal of Business, Vol. 5, No. 2, pp. 207-219

32. Ndubisi, N.O., (2006), Effect of gender on customer loyalty: a relationship marketing approach, Marketing Intelligence \& Planning, Vol. 24, No. 1, pp. 48-61

33. Narver, J.C., and Slater, S.F., (1990), The effect of a market orientation on business profitability, Journal of Marketing, Vol. 54, No. 4, pp. 20-35

34. Oliver, R.L., (1981), "Measurement and Evaluation of Satisfaction Process in Retail Settings," Journal of Retailing, VOL. 57, pp. 25-48

35. Oliver, R.L., (1999), Whence consumer loyalty?”, Journal of Marketing, Vol. 63, pp. 33-44 
36. Patsioura, F., Vlachopoulou, M., and Manthou, V., (2009), A new advertising effectiveness model for corporate advertising web sites: A relationship marketing approach, Benchmarking: An International Journal, Vol. 16, No. 3, pp. 372-386.

37. Parasuraman, A., (1998), Customet Service in Business-to-Business Markets: An agenda for research, Journal of Business and Industrial Marketing, Vol. 13, No. 4/5, pp. 309-321

38. Peeler, G. H.,(1996), Selling in the Quality Era. Blackwell Business, USA

39. Pitt, L., Caruana, A., and Berthon, P.R., (1996), Market orientation and business performance: Some European evidence, International Marketing Review, Vol. 13, No. 1, pp. 5 - 18

40. Sila, I., and Ebrahimpour, M., (2005), Critical linkages among TQM factors and business results, International Journal of Operations \& Production Management, Vol. 25, No. 11, pp. 1123-1155

41. Slater, F.S., and Narver, J.C., (1994), Market orientation, customer value, and superior performance, Business Horizon, March - April, pp. 22-28

42. Slater, S.F. and Narver, J.C. (1995), Market orientation and the learning organization, Journal of Marketing, Vol. 59, pp. 63-74

43. Slater, S.F. and Narver, J.C. (1999), Market orientation is more than being customer led, Strategic Management Journal, Vol. 20, pp. 1165-8

44. Taleghani, M., Gilaninia, S., and Mousavian, S.J., (2011), The Role of Relationship Marketing in Customer Orientation Process in the Banking Industry with focus on Loyalty (Case Study: Banking Industry of Iran), International Journal of Business and Social Science, Vol. 2 No. 19, pp. 155 - 166

45. Wouters, J.P.M, (2004), Customer Service Strategy Options: A multiple case study in a B2B setting, Industrial Marketing Management, Vol. 33, No. , pp. 583-592

46. Zineldin, M., and Philipson, S., (2007), Kotler and Borden are not dead: myth of relationship marketing and truth of the 4Ps", Journal of Consumer Marketing, Vol. 24, No. 4, pp. 229-241 